

\title{
Molecular detector (Non)Technology in Mexico
}

\author{
Luis Reyes-Galindo ${ }^{1}$
}

\author{
"En política nunca anuncies, actúa..." \\ -Carlos Fuentes, La Silla del Águila
}

\section{Introduction}

While the relationship between scientific experts and the wider society they are immersed in has been a salient topic for contemporary STS (Collins and Evans 2002, Wynne 1992, Jasanoff 1990), as Shrum (2005) has pointed out, there has been no sustained effort to examine such issues in "peripheral" science and technology contexts. Sagasti (1973) has also remarked that the relationship that "underdeveloped" countries have with science and technology, and with the "developed" nations where it is produced, is a complex one that cannot be understood by simply transposing the structures found in "Global North" scholarship to the "Global South" (GN and GS, henceforth). Unlike in the GN, where power, development and political legitimacy have been historically closely linked to science and technology (Jasanoff 2004), in the GS scientific and technological cultures are often at a loss in inter-institutional settings (Rodríguez Medina 2014, Shrum and Shenhav 1995). STS in the GS faces the dual challenge of exploring how scientific knowledge and expertise are shaped across cultures, and how differences in institutional power relations should be scrutinized - particularly when the exchanges involve flows across North-South boundaries (Kreimer 2006).

This paper presents a case study of how a particular instance of "technology transfer" from GN to GS played out in Mexico. The case is relevant to contemporary discussion of the impact of technological expertise precisely because, unlike GN contexts, in Mexico a full culture of evidence-based policymaking is generally lacking amongst the political elite and bureaucracy. Empirical studies in Mexican science-policymaking relations show that, in contrast to traditional outlooks on politics and governance, "non-knowledge" and "managed ignorance" are acceptable tactics used by the Mexican State to exercise sovereignty and impart order (Mathews 2008, 2013; Bonneuil et al. 2014), particularly in controversies that involve politics (Schoijet and Worthington 1993) and organized crime (García-Deister and López-Beltrán 2015).

The case involves so-called "molecular detectors" (MDs), artifacts that have periodically appeared, disappeared and reincarnated into the global security and military market since the early 1990s. ${ }^{1}$ Although MDs are claimed to work on a variety of scientific principles, direct physical examinations of the devices has shown that the devices are empty plastic boxes with no working electronic parts. Independent, double-blind testing has shown that MDs work no better than chance. In addition, according to an extensive amount of investigative reporting, independent citizen inquiries, whistle-blower accounts, judicial investigations and formal military and scientific testing, these devices were never intended to work through sound scientific or technological knowledge, yet were shrouded by manufacturers in a blanket of scientific discourse. Manufacturers have claimed that solid scientific principles supported MD "technology," but existing evidence and recent legal rulings have reached the conclusion that - at least for the devices involved in the Mexican case - MDs were always known to be non-functional by manufacturers. $^{2}$

\footnotetext{
${ }^{1}$ E-mail: luisreyes@ciencias.unam.mx
} 
The paper focuses on how MDs were introduced in Mexico, on individual efforts by scientists and "scientific skeptics" to influence political and legal institutions to ban MD use, and on the institutional negligence that followed. ${ }^{3}$ The paper will challenge two assumptions in STS discussions that, though valid in GN contexts, do not apply to the Mexican state: that science is an institution that has deep (some would say, excessive) influence on policymaking, and that the separation between "scientist" and "citizen" interests is unproblematic. The story of MD use in Mexico could be written as a political farce in which top ranking military officials, senior civil servants, security experts and the mass media were comically duped into spending millions of dollars for useless plastic boxes, were it not for the fact that the use of these devices has had tragic consequences for thousands of ordinary Mexicans. In the recent fraud conviction of MD manufacturers in the UK, the gravity of the sentence handed out reflected the damage attributed to MD use in high-risk settings. ${ }^{4}$ In Mexico, MDs have been used to illegally detain and imprison thousands on what could be bogus drug-related and gun-trafficking charges: according to recent investigative journalism, over 5,000 individuals have been detained based on MD "proof," despite no other evidence to support the charges; 1,980 remain in custody and 625 cases of convictions to federal prisons have involved MDs. ${ }^{5}$

Could these wrongful convictions have been avoided? How can a peripheral country like Mexico face the introduction or imposition of new technologies? What role is there for STS scholarship in examining such cases? Like in other Mexican settings where science and technology is resisted (Bonneuil et al. 2014, Brandt 2014), the importance of organised, critical civil society is shown to be paramount in the Mexican case. The proposition here, however, is that in techno-scientific peripheral countries like Mexico, the institutions of science are far from generally being relevant actors within civil society, universally influential in important government decisions where science comes directly into play, or see it as part of their aims to produce social impact or justice even when there are opportunities for direct involvement. I propose that in the Mexican context, rather than simply 'curb the power' of scientific institutions when facing civil society to achieve social justice, STS may better act according to local needs by encouraging science as part of civil society. It is by solidly building these links between science and society that, in the present case, a country like Mexico could come to terms with imposed technologies that are enforced from outside.

A note on terminology: the term (non)technology is introduced in the title to point out that MDs displayed some of characteristics of "genuine" technology for a limited duration - if one is to use "technology" in sociologically-informed sense - yet also missed the mark in other crucial aspects. Just like "real" technology, (non)technology requires a social matrix on which to thrive, but what makes the MD case challenging from an STS constructivist perspective is that the dispersion of MDs depend almost exclusively on sociological elements. The MD case brings to mind Winner's (1993) classic challenge as to whether technological constructivism and other related STS frameworks can - despite analytical successes - create a situated political stance in cases that desperately require critical assessment of technology.

\section{Molecular detectors and the Mexican "War on Drugs"}

For more than a decade Mexico has been scarred by a prolonged "War on Drugs" between rival drug cartels, organized crime and the government that has deeply affected its social fabric (Campbell 2014). The conflict rapidly escalated in 2006 after controversial, full-scale government military intervention became the official position to deal with the cartels' increasing power (Kellner and Pipitone 2010). The extreme violence, which to that point had almost exclusively characterized inter-cartel conflicts, rapidly spread, accompanied by spine-chilling 
public displays of violence, as well as social deterioration far beyond any that the country had previously experienced from drug trafficking (Vuillamy 2010, Hernández 2010). Anti-journalist violence, police and military harassment, corruption, kidnapping and murder statistics consistently place the country in the lowest end of global indicators on freedom of expression, media independence, journalist deaths and human rights violations (Lutz 1996). Official figures from the 2006-2012 presidential period place the death toll directly related to drug violence at around 60,000; yet other governmental statistics point to more than 120,000 organized crime violent deaths. ${ }^{6}$

It was in this context that in 2008 one of the widest-circulating national newspapers featured an article on the Mexican Army's use of a device referred to as a "remote substance detector or molecular gun," the GT-200.7 The MD was sensationally portrayed as powerful technology recently arrived in Mexico that would bring the cartels to their knees. It was reported as also being in use by the British military. This "Devil's Ouija" was said to be used to remotely detect drugs, explosives, weapons, money, missing persons, tobacco, toxins, explosives, ivory, amongst other substances, using "diamagnetic fields" and "paramagnetic fields" purportedly emitted by these substances from extremely large distances and even underground and underwater. The battery-less device was claimed to have the advantage of being highly portable and only required "static electricity" provided by the user. The GT-200 was described as the National Defence Ministry's (SEDENA) newest frontline weapon against organized crime in its highly publicised National Security Strategy. ${ }^{8}$ Significant press coverage of the molecular detector's success continued to appear in the written press, mostly as rewrites of government press releases documenting detectors' successful field applications in locating drug shipments, cartel safe-houses, making arrests, etc.

But despite the positive portrayal in the Mexican media, MDs' legitimacy had been disproved a number of times by military agencies since their appearance in the US in the mid1990s. MDs such as the Quadro Tracker, MOLE Programmable Detection System, GT-200, Sniffex, $A D E-651$, to name a few, had been debunked both by theoretical analyses, physical examinations and double-blind field tests carried out at Sandia National Laboratories and by the US Navy's Counter Terrorism Technology Task Force (Murray et al 1998; Murray 2002, US Navy 2008). When opened (despite manufacturer's legal threats) MDs were discovered to be empty plastic boxes with swivelling antennae - sometimes adorned with decals and fake electric wiring - which were being sold in the international weapons and security market as advanced technology based on sound scientific principles. MDs were simply dowsing rods that were being commercialized as high-tech instruments. These early tests had led to injunctions, bans and criminal investigations against a handful of MD manufacturers in the US and EU. Nevertheless, the bans were easily circumvented by creating new "iterations" of the devices (e.g. cosmetic modifications plus name changes), which allowed them to be marketed to developing and underdeveloped countries. War-ridden nations such as Iraq and Afghanistan were major fraud targets, with the Iraqi case leading to corruption charges against top-ranked military officials. ${ }^{9}$

Very little concrete information exists on how the MD (non)technology first entered the market in Mexico, although it seems that -as in other places in the GS where the devices were introduced-MDs were directly marketed to government agencies by what in appearance were legitimate import companies specializing in security and military equipment. ${ }^{10}$ In Mexico the main importer of the GT-200 was the company SEGTEC S.A. de C.V. which still has an online presence and claims to specialize in selling "vanguard technology... for security, detection, intelligence and counterintelligence" to both private and public consumers; SEGTEC used to advertise the GT-200 in its website portfolio, but has now removed the device from its offered products. ${ }^{11}$ Freedom-of-information requests from various government agencies and purchase 
contracts have indicated that the devices were acquired in many cases following "demonstrations" by suppliers, who in some cases also provided "training courses" along with the operating manuals. Yet in most cases, there were not formal tests of the devices by the government agencies themselves, and the general impression is that the devices were purchased without even minimal questioning of sellers' claims. Government agencies were passive purchasers of "miracletechnology" from what appeared to be otherwise reputable sellers (Reyes-Galindo 2012).

Recent post-colonial scholarship on Latin American STS has argued for the need to go beyond the vision of technology flow into the region as a form of passive reception of "imported magic" (Medina et al. 2014), and though the essays in that volume convincingly showcase how many technologies are reconfigured or appropriated in Latin American contexts (see also Brandt 2014), the MD case would seem to be an anomaly in this line of thought, an example of how in MDs indeed came into the scene as "imported magic." I will therefore argue that, in the MD case, Mexico suffers from being peripheral not just in terms of its position within global technology networks, but also -and perhaps more importantly- in terms of global power imbalances and its institutional socio-technical ability to cope with these power/knowledge asymmetries. Mexico appears to have one foot in the post-colonial condition of immersion into global technology networks which it can partly adapt to and appropriate, and another in an apparently colonized, "dependency relation" in which it has little ability to challenge incoming technological tides critically (Beatty 2015). Indeed, Anderson (2009) and other post-colonial scholars have argued that semi-dependency "de-colonial" scenarios like these, common across Latin America, simply make globalization a new form of old North/South military colonialism (Maldonado-Torres 2012, Quijano 2007).

\section{The ADE 651 and the Newsnight investigation}

The ADE-651, manufactured by Global Technical Ltd. in the UK became infamous overnight in January 2010, when it was featured in an investigative report on MDs broadcast on the $B B C$ Newsnight television show. ${ }^{12}$ Scientists from Cambridge University who physically examined an ADE-651 found that the outer electronics were useless cosmetic wiring and concluded that they were, without a doubt, fake "technology." In response, the UK government took immediate action, one day later banning all exports of bogus MDs to Iraq and Afghanistan where British troops were stationed. ${ }^{13}$ The warning was put forward on 5 January, 2010, but Newsnight noted that the Foreign Office had been aware of the device's inefficacy since March 2009, yet had failed to warn the Iraqi government until November of that year. Newsnight also showed that between 2001 and 2004 technicians from the Royal Engineers had been hired to promote the ADE-651 at arms fairs around the globe. A common thread across all the MD cases has been this reliance on the trustability of technology that is sourced from 'reputable' sellers and manufacturers. It is the image of technology as an inscrutable, quasi-magic object that lends it an air of infallibility. Iraqi Major General Jehad al-Jabiri, head of the Ministry of the Interior'sGeneral Directorate for Combating Explosives was reported by the NYT as declaring about the detectors: "Whether it's magic or scientific, what I care about is it detects bombs". ${ }^{14}$

The GT-200 was in fact advertised by manufacturers as officially tested and sponsored by the Royal Engineers. Documentary evidence shows that MD testing was carried out at RE installations and given a favourable assessment. Responding to a query on the case by anti-MD blogger "Techowiz," Quentin Davies, Parliamentary Under-Secretary of State, acknowledged that a Defense Export Services Organization test of a Global Technical device at the Royal School of Military Engineering in Chatham was carried out by an Export Support team 
"comprising of serving military personnel provided by the MOD." The letter, however, claimed that

Global Technical Ltd [...] produced a report that was described as a "trial.” It should not have been described in that way as it did not meet the MOD criteria for a formal trial. Separate Army Trials and Development Units exist for that purpose. ${ }^{15}$

The allegedly RE sponsored report "Trial of GT200 Programmable System Detector" published online by ADE-651 manufacturers has since been taken offline, but was made available by British anti-MD bloggers who have been instrumental in bringing these and other MD documents to light. ${ }^{16}$

\section{Activism against molecular detectors in Mexico, part I: the blogosphere}

An important public voice against MDs has been "skeptic" magician James Randi, who as early as 1996 issued a US\$1 million (unanswered) public challenge to ADE-651 manufacturers to prove their device could work, published in the James Randi Foundation blog. In addition, a number of bloggers began gathering documentary evidence and denouncing the various MDs being used around the world. Blogger "Techowiz," "Fraud hunter, who hates people who make money at the risk to other peoples [sic] lives," focused mostly on the ADE-651 since 2008; "Peter Robinson," "Fraud buster and hater extraordinaire. Conqueror of the conmen," also focused on the ADE-651 and more recent frauds like the GT-200; Bristol University professor Bruce Hood, also interviewed for this work, has blogged on MD frauds using the results of psychological studies on paranormal beliefs. Anti-MD blogs typically also link to the "scientific skeptic" blogosphere, where MDs are denounced as a particularly vile incarnations of "pseudoscience."

In Mexico, MD frauds were copiously documented by skeptic blogger Andrés Tonini, whose blog is currently one of the most complete repositories of worldwide MD fraud information. ${ }^{17}$ Despite continued bureaucratic resistance from Mexican government agencies to reveal real MD usage, on-line activist freedom-of-information requests estimate that government agencies have spent at least $\$ 26$ million dollars on bogus detectors, most of them ADE-651s and GT-200s. Tonini and other activists have also documented how the purchases were made when it was already public knowledge that the devices were fraudulent and that no independent testing was carried out before the purchases were made.

Activist bloggers also made significant use of social media to disseminate information on MDs to the public. Twitter was used to attempt to contact Mexico's most prestigious journalists, though with little success. Tonini recounts that only 2 replies were received after contacting 60 prominent journalists and 50 national media outlets. Tonini continues to monitor the national press coverage of the topic, runs a dedicated Facebook page on MD frauds and has continuously blogged about his frustration with the media's disinterest. Tonini summarized:

Tonini: The Mexican press's role has been pathetic. It was only after [a piece in] Milenio newspaper that the topic started being discussed outside the Internet, but if newspaper readers are a small minority in this country, readers of newspaper science columns are a minority within this minority, so in practical terms this amounted to nothing. [...] In fact, not even the front page articles by Laura Castellanos in El Universal [...] and by Patricia Dávila in Proceso [...] turned this topic into what it should really be: a national 
scandal. Printed-media readers are a small minority in Mexico and the main source of information in Mexico -television- has with very few exceptions not only ignored the topic, but in fact highly praised the alleged abilities of these devices. ${ }^{18}$

The lack of a critical press in Mexico regarding MDs - dissimilar to the UK case in which Newsnight report was a breaking point - is a pivotal dimension in the evolution of the controversy and in framing the MD issue not just as a case of subject-based ignorance, but as one of widespread social misinformation that was maintained by actively keeping the issue "invisible" and out of the public eye (Reyes-Galindo 2012).

\section{Activism against molecular detectors in Mexico, part II: scientific activists}

A second front against MDs in Mexico is a small group of individual scientists. In the MD controversy it is not the "non-scientist citizen" who is the voice of opposition to power, but rather the individual scientists that take up the role of "anti-establishment laypersons," "interested citizens" and "activists." Most important is Luis Mochán, a senior physics researcher who has widely written and spoken against the detectors in both academic and non-academic settings. Mochán recounted his initial chance encounter with MDs:

Mochán: In one of the weekly notices of the APS [American Physical Society] newsletter there was a bit of news about Mexico, saying that Mexico had been victim of fraud because we'd purchased these devices, described exactly as the ones I'd seen before [at a meeting where James Randi was an invited speaker]. That left me very worried, and I decided I wanted to write something about it, but a long time passed [...] even though it was still in the back of my mind. I talked about it with friends and family, until one day I learnt from a neighbour that in the school next-door to my own house they'd actually gone in with their GT-200. That made me feel really angry... and nervous... to feel it so close. $^{19}$

Mochán's direct involvement in the GT-200 controversy began with an article written for a local newspaper ${ }^{20}$ which he mailed to local politicians. Sen. Yeidckol Polevnsky, shocked to read about the case but thinking it was a joke, contacted Mochán. After hearing the details of the case, Polevnksy decided to raise the matter at the Mexican Senate floor. The Senate then contacted the Scientific Consulting Council of the Presidency (Consejo Consultivo de Ciencias, or CCC), a body of top scientific advisors to the President of Mexico, which replied that an investigation should be made on the subject. In September 2011, the Senate's Science and Technology Workgroup organized a formal meeting with "eminent scientists" to discuss the MD case. Invited speakers included Mochán, Tonini and a handful of directors of major scientific institutes and scientific societies. The scientific opinion was unanimous: no evidence had ever been provided or could be reasonably formulated that the detectors worked based on any accepted physical principles cited by manufacturers. The final talk, given by Tonini, was based on his extensive documentary effort, concentrating on the international bans, injunctions, arrests and international scandals surrounding the molecular detectors' parent companies. ${ }^{21}$

A non-binding "sense of the Senate" resolution draft was written to establish the Workgroup's agreement that MD efficacy needed to be scrutinized immediately and was presented at the Senate the following day. A formal resolution was not presented to the Senate plenary until eight months after the meeting, but in a much tamer tone, calling on the government only "to evaluate the effectiveness and functioning of the GT- 200 molecular 
detectors purchased by the Mexican government." An even weaker final draft recommended "the organization of workgroups with the Mexican scientific community and departments from the federal public administration" to discuss the device's efficacy. The resolution ended by noting that it was the CCC's duty to formally advise the Presidency concerning technical matters and that the evaluation of the GT-200 should be delegated to it (no mention is made of the ADE651, which during the Senate meeting Tonini had clearly stressed was also being used in Mexico). ${ }^{22}$ The CCC, however, never issued any official pronouncements on the MD case.

\section{Bogus molecular detectors as court evidence in Mexico}

The Senate's involvements had no real practical outcomes and bloggers continued documenting extensive MD use by military personnel. In March 2011 Reforma newspaper published an article in which Mexican Academy of Sciences (AMC) president Arturo Menchaca was cited as denouncing that MDs were fraudulent devices, contrasting them to real detector technology as used, for example, in airport security checkpoints. ${ }^{23}$ Upon reading the article, Mochán decided to contact the Reforma journalist, who showed further interest to write about MDs. Some weeks later, Mochán was contacted by the defense lawyer in a case involving an arrest carried out using the GT-200 who read the Reforma articles. Agreeing to help, Mochán carried out a detailed analysis of the GT-200 operation manual that could be used by the lawyer in court:

Mochán: The lawyer forwarded me the MD operators' court statements. Each time they arrest someone using the detectors, the operator goes before the judge and describes how they were walking down such and such street, and then how the MD antenna turned pointing towards such and such place. After this account, they explain how the detector works [based on the MD manuals]. I had eight of these statements at hand, all identical, so obviously it's just a cut-and-paste text. ${ }^{24}$

Mochán suggested to the lawyer that the most objective way to proceed was to carry doubleblind testing and thus empirically prove that the device did not work. Much to his surprise, the lawyer told him it was not a strategy likely to succeed:

Mochán: I told the lawyer, "look, this is obviously bogus. What we need is for the judge to order a double-blind test." The lawyer explained to me that in Mexico a judge will never order such a test, unless from the start the judge has an argument which contradicts a previous one. So what I did was to analyse the molecular detector technical specifications line by line, which I thought was absurd given what the technical specifications say, but I still did it anyway. ${ }^{25}$

Mochán published a report of his findings on his own personal blog, in which he carefully argued why the results could not work from physical first principles (Mochán 2011) and was called in as a court expert to provide formal evidence against GT-200 usage. Unfortunately no public information exists on whether the case has been resolved. In a related case that gained visibility when picked up by the widely circulated El Universal newspaper, Ernesto Cayetano, a member of the mixe indigenous group, was detained on drug charges after having been "pointed out" by a bogus detector at an Army checkpoint. ${ }^{26}$ Cayetano's case was taken up by a young district judge who upon scrutinizing the accusing party's arguments based on detector "evidence" decided to use scientific expertise to judge their efficacy. Mochán's analysis of the user manual eventually led 
to Cayetano's release, and there are at least two similar cases where Mochán's work directly led to releases. ${ }^{27}$

During that time, the Mexican Human Rights Commission issued an "official recommendation" on the GT-200, described as a "device [used] for the detection of drugs, weapons and explosives, amongst other substances, which functions using the static electricity produced by the human body." 28 Although the recommendation acknowledges that foreign governments had deemed the detectors fraudulent, it also stated that "the fact of its being used, independently of its effectiveness or lack thereof, is a violation to individuals' right of privacy in their homes." The Report thus refrained from accepting the scientific consensus that MDs were bogus devices. CNDH president Raúl Plascencia Villanueva later spoke out against the use of the detectors, but surprisingly referred to them as devices "more fraudulent than trustable," in opposition to scientific opinion that there could be no science behind MDs.

Previous studies on controversies linked to imported technologies in Mexico have similarly highlighted the extraordinary difficulties for local, citizen and activist positions to effect an impact on local politics and policy. In their study of Zapatista corn Bonneuil et al. (2014) illustrated how local knowledge about corn is turned "invisible" in global scientific debates on genetically modified food, which in turn allowed the Mexican government to manage it as "non scientific" and overturn previous anti-GM policy to conform to agro-industry views. Mathews (2008, 2013) has carried out extensive ethnographies of the epistemic practices of Mexican forestry agencies, concluding that secrecy, disinformation and misinformation are consistently used in Mexican policymaking practices; but, as in the present work, he has also pointed out the deeply negative consequences that this has for policy outcomes. The MD case is another example of how "ignorance" and rendering knowledge invisible are part of Mexican civic epistemologies, or the "institutionalized practices by which members of a given society... test and deploy [or make invisible] knowledge claims used as a basis for making collective choices" (Jasanoff 2005).

\section{The GT-200 in court: Mexico and UK}

In a case that would turn out to be critical to the MD scandal, the GT-200 was used by the Mexican Army to detain two women on drug-trafficking charges. The presiding judge, however, accepted the demand that the GT-200 be scientifically tested. A double-blind test was planned where only the Army's "expert users" would handle the device themselves, in order to avoid later objections that MDs had been mishandled. The test occurred in November 2011 at a warehouse owned by the Mexican Academy of Sciences with a double-blind protocol designed by Mochán and a fellow physicist from Morelos state. The final report concluded that "the GT200 proved completely ineffective as an instrument to detect the substances and munitions used as the sample when the operator ignores beforehand where the substance has been hidden" (Mochán and Ramírez-Solís 2013). The report was subsequently published in the arXiv preprint server, one of the most widely used paper dissemination platforms in the physics profession.

In response, the Mexican Attorney General's office filed an appeal that challenged the decision to discard the GT-200 as court evidence. Supreme Court minister J. R. Cossío Díaz used the Court's power to assert jurisdiction on high-relevance appeals ("facultad de atracción") hoping to establish binding precedent for future cases and to determine "if the data produced by this detector can be considered as evidence in penal processes." ${ }^{29}$ As a stalling tactic, the Defense Ministry refused to provide the GT-200s for testing and eventually the General Attorney's Office dropped the challenge. The detectors were thus never tested and no legal precedent against MD use could be established. According to its last publication on the topic, the Supreme Court has 
ruled similarly to the HRC recommendation - only in respect to molecular detector evidence not being grounds for home searches and thus establishing only very limited restrictions on MD use. $^{30}$

Nevertheless, the arXiv report was picked up by the MIT Technology Review blog, giving it additional visibility. ${ }^{31}$ London police noticed this post and Mochán was requested to provide oral evidence based on the published analysis against British MD manufacturers Gary Bolton and James McCormick. Ironically, while being continuously ignored in Mexico, Mochán testified at the Old Bailey criminal court in the trial that eventually led to Bolton's incarceration (Bolton received 7 years, McCormick 10). It was also learnt that Bolton's company made $£ 3$ million per year, with each MD selling for around $£ 10,000$. McCormick sold approximately 7,000 devices, with total profits of around $£ 50$ million. Two other individuals have been since convicted in the UK on MD frauds. ${ }^{32}$ In Mexico, not a single individual has stood trial regarding MD purchases, sales promotion or misuse.

\section{A view from the other side of the controversy: users' belief in molecular detector efficacy}

Accounts by scientists involved in the case provide an indirect view of MD military users' perspectives. In his presentation during the Senate meeting, UNAM physicist Alejandro Frank described his experience discussing MDs with Mexican Navy personnel who had actually used them in the field. In Frank's opinion, MD users definitely did believe that the MDs were based on top-of-the-line technology:

Frank: I've had the opportunity to occasionally talk to personnel from the Navy and I've come to realize that they sincerely believe that these devices work. The scientific community is not affirming there is bad faith behind the purchase of this equipment. We do think, however... that you are underutilising the country's scientific capacity to make decisions. ${ }^{33}$

When Mochán had the chance to test the detectors alongside Army personnel during the AMC tests, he similarly observed that users were genuinely shocked at the end of the trial to find out the device did not work:

Mochán: Everyone who went to carry out the test was participating with very good will. Nobody was really trying to fool us. The [Army] people who were working the devices did believe the devices worked at the beginning of the test, and they did everything very, very honestly.

While the skeptical literature and the scientific critique has concentrated on individualistic, psychological explanations of "fraud", the psychology of error and "pseudoscience" to explain MD proliferation, ${ }^{34}$ these accounts fail to elucidate the breadth and locality of the MD phenomenon across different national settings. Individualistic accounts, for example, fail to fully explain why the phenomenon played out so markedly different across the GN/GS divide, while serious accounts of fraud require a much more comprehensive sociological scrutiny.

To understand the proliferation of MDs one must note that unlike in GN settings, scientific-military relations in Mexico are generally moulded by deep, historical antagonism and even hostility (López-Montiel 2000). The FOI queries gathered by Tonini show that although 
the first two government agencies to purchase the detectors claim to have "tested" the detectors, no information was provided as to how the tests were carried out; other government agencies admitted to purchasing the devices without carrying out any sort of testing (Tonini 2010). Insofar as can be gathered from the available documents, the purchases were made after nonrigorous "demonstration" sessions by the bogus detector marketing companies. Frank reported to have his help refused by three different Navy senior officers, even when extreme discretion on testing results was also offered (Dávila 2012). According to anecdotal accounts from different scientists involved in the controversy, military personnel made personal comments regarding higher-ranking officers blatantly ignoring technical experts within the military organization that were skeptical of MDs. Online military discussion forums dealing with the GT200 and other detectors often include strong opposition to scientific opinion when it challenges military views:

Military discipline [...] is something that you clearly do not understand. I've read your posts and even though you think we have "blind faith" [in the detectors] this has nothing to do with faith. Military orders always have a reason for being, but it is clearly something that only we in the military understand.

With all due respect to fellow users, these [molecular detectors] really do work. If the SEDENA, SEMAR, PGR and all other nationwide police forces are using it, do you think they really can't work? I'm no physicist or a chemist, but the government would not spend so much money on devices that don't work!

Also, despite the fact that the Army is often involved in corruption scandals, major human right violation cases and mass killings, national perception polls consistently find that public trust on the Army remains reasonably high and that the public has extremely high approval ratings for the use of the military in curving cartel and organized crime (Mitofsky 2014). In contrast, public perception of science is at best ambivalent according to empirical investigations such as the National Poll on Public Perception of Science and Technology (ENPECYT). ${ }^{35}$ Other consultations run by the Mexican National Academy of Sciences and UNAM confirm this trend (De la Peña 2005). In this sense, not only did anti-MD activism have to play out within a social system where the perception of science is initially weak and of the military sentiment strong, but also had to oppose an institution that has a much greater political and social standing.

There is strong evidence that top ranking officials were heavily involved in corruption and bribery in relation to detector purchases, similar to the pattern found in other countries by the British MD criminal trials. Mexican investigative magazine Contralinea reported that a highlevel Army colonel recently committed suicide after an official investigation was begun related to charges of corruption in several multi-million dollar purchases of military equipment, including MDs. "Sources from the National Defence Ministry sustain that [the colonel] was under enormous pressure due to an investigation against him from the Armed Forces General Accounting Investigations Office, and also because of the audit on the purchase of the GT-200 alleged molecular detectors, that meant a fraud was committed against the Ministry and the federal treasury amounting to MX\$211 million [around USD\$20 million]." 36

There is of course the possibility that the Military might have been fully aware of MDs ineffectiveness and that they knowingly used a constructed (non)technology facade to enforce discretionary power, but the hypothesis sits outside empirical access, barring of a full-blown internal investigation. As Rappert and Balmer (2015, page 334) point out, using various forms of ignorance and secrecy as a strategic device is a common practice in military, intelligence and security settings, and yet "often lack of disclosure about the basis for such evaluations and the use 
of hypothetical scenarios to justify contested technologies has raised doubts for some." The limited documentary evidence and freedom-of-information documents do not by themselves confirm or refute this hypothesis. While some government agencies and local institutions claim to have "tested" the devices or have witnessed tests, others confess to have simply purchased them without much thought on the matter of efficacy. The military agencies had been approached by a sufficient number of reputable individuals decrying the fraud, yet the Executive branch at the highest levels not only resisted but indeed actively fought against the criticism in court. My analysis of the MD case is rather more damning than Rappert and Balmer's position: by ignoring the views of interested citizen-scientists and citizen-activists and that of the international scientific community around the devices, the Mexican government turned MDs into an instrument of violence; violence as "[the] capacity to allow arbitrary decisions, and thus to avoid the kind of debate, clarification and renegotiation typical of more egalitarian social relations" (Graeber 2006).

\section{An ambassador intercedes}

Finally, the blatantly unethical role of external actors using national-scientific prestige and carrying out political lobbying to "push" MDs into an already vulnerable social matrix should be strongly scrutinized. There is ample evidence of significant involvement by the UK Government in promoting the detectors during the first stages of the Mexican episode. Even discounting the infamous Royal Engineer Report, ${ }^{37}$ investigative journalism aided by blogger activism has shown that the British embassy was actively involved in promoting meetings between MD salesmen and Mexican government officials, paving the way for consultations between convicted fraudster Gary Bolton and high ranking Mexican politicians for a modest fee (Booth 2014). While exAmbassador Giles Paxman claimed he was always unaware that the devices were fraudulent, Freedom of Information Act documentary evidence shows the Home Office had analyzed Bolton's detectors eight years prior to the Mexican controversy and that memos warning about the scam had been widely circulated in Whitehall and various branches of government. Documentation obtained by investigative journalists also shows a Trade and Investment Officer from UKTI, based at the British Embassy in Mexico, describing to Bolton how UKTI had arranged presentations with National Security and Attorney General personnel from Jalisco state to promote Bolton's product, as well as future possibilities to open a market with the state of Baja California Norte (both Jalisco and Baja California are territories suffering strongly from cartel violence): ${ }^{38}$

Giles Paxman has already sent introductory letters to Municipal and State Governments in Baja California about the world-class status of the UK security industry and our offer to travel to Mexicali and Tijuana with relevant UK companies (hopefully yourselves) in order to deliver presentations on innovative technologies that can be of great interest to them.

However, when the scandal erupted in full, the Government washed its hands declaring that these were simply "common practices" in promoting British products abroad, but as Ennals (2014, p. 138-139) comments on the case:

We are left with questions of responsibility. The fraudster has been jailed. An ambassador was retired but without explanation. [...] The UK is committed to supporting UK arms manufacturers. They seek international markets, but are wary of publicity. They make it 
clear that the government accepts no responsibility for the products sold, and their subsequent use, but potential customers may have a different impression. Of course, if transactions are shrouded in secrecy, difficult questions will not be asked.

Not without irony, and despite the havoc, injustice and violation of human rights that were enabled by British legislation that permits (non)technology to be used in settings where there are no immediate British interests at stake, Mochán's expertise and testimony were utilized by prosecutors in the UK to convict notorious MD fraudsters. Although the British Embassy in Mexico declared that the promotion of MD devices stopped when it was learned that the MDs involved fraudulent technology, Mochán himself has remarked upon the ample documentation that shows the Embassy's active involvement at a time when the devices were known to be ineffective. The documentary evidence shows that the Embassy should have been aware the devices were fraudulent, but neither Paxman nor any other British official has ever been called into account. ${ }^{39}$

The patent disregard for anything lying outside of immediate British interests and British lives reminds one of Kurt Vonnegut's diatribe against imperial attitudes in Bluebeard: "This state of mind allows too many of us to lie and cheat and steal from the rest of us, to sell us junk..."

\section{Institutional responses to MDs in Mexico}

According to Levi $(2008,392)$ for the occurrence of large-scale international fraud to occur a variety of conditions must be met, so that "offenders may start with differential access to local, national or international resources, but the exploitation of inter-state and international regulatory and criminal justice asymmetries-e.g. different levels of enforcement in the states or countries in which the fraudsters operate-represents a positive advantage for fraud compared with most other crimes." In order to analyze the Mexican MD fraud beyond a reductive psychological framework, one must therefore structure the episode beyond a "confidence trick" set-up in which manufacturers and Mexican military personnel respectively played the roles of fraudsters and "marks" (Schur 1957). In this paper I have illustrated that the Mexican MD case was indeed framed in the social and cultural characteristics required by Levi - a deteriorated political environment and a failed national policy to curb cartel influence; pre-existing high levels of institutional corruption; timid opposition from non-military institutions inside Mexico such as the press, judiciary and legislative powers; and finally, the role of a powerful external actor with access to political influence in the British government's deep involvement.

However, being a case of technological fraud and given its envelopment in the rhetoric of science, it remains to be explained why the scientific community did not act as a barrier or a voice to the fraud. Although individual scientists such as Mochán, Frank and Menchaca played a role in voicing their opinion on MD usage, the role of scientific institutions, which could have supported their position, turned out insignificant:

Mochán: The AMC [Mexican National Academy of Sciences] has manifested its opinion only through the voice of Arturo Menachaca, never institutionally. The Academy has never taken a stance, except when Menchaca sent a letter to the Secretary General of the Defence Ministry as President of the AMC, offering the help of the scientific community to design a test protocol. 
Similarly, when the Supreme Court approached the AMC for help in analyzing the Attorney General's appeal, the AMC did not take a proactive stance and made no public pronouncements. In another description of the scientific community's lack of institutional involvement, Mochán explained how UNAM's collegiate bodies consistently ignored his pleas to take an institutional position regarding the detectors, notwithstanding the fact that they were aware of the harm the devices were causing. This is not trivial, as UNAM's political leverage is extremely important in Mexican national politics and official pronouncements from the University have definite political weight:

Mochán: It is very troubling that universities have not involved themselves in the discussion. I sent a letter to the Consejo Universitario [the highest collegiate body within UNAM] ... and they said, "no, no, this type of public engagement is uncommon. You'd better make this letter disappear." I withdrew the letter, but they promised that the Consejo Técnico de la Investigación Científica [CTIC, the highest ranking UNAM scientific collegiate body] was going to take up the subject. But they said to me "look, it's better to not make a fuss about it. It's better to negotiate and speak person-to-person with these people" ... The director of the institute I work in talked to the UNAM Attorney General about the matter, but the Attorney said the only thing the CTIC could do was to suggest a public test, and only that. They preferred to "let it die in silence."

Mochán was also explicitly warned that at no time should he present his position as that of UNAM, making any possible critique of the detectors merely as the opinion of a lone individual. ${ }^{40}$

Mochán: It would be trivial to have an institutional position on the subject [through the CTIC] instead of the opinion of a lone madman. I've been warned, "Be careful. You and only you are responsible for anything you say. That is not what UNAM says. Don't dare to go on and say that is UNAM's opinion." And why the hell should UNAM not have an opinion?! Of course I can't talk for UNAM, but there are people who could. Why don't they do it? That not only makes me feel hopeless. It quite angers me.

In a similar fashion, though directly supporting the President (the head of the Mexican Armed Forces) the CCC also abstained from emitting an institutional response:

Mochán: The President of the CCC is my friend. He is supposedly a personal advisor to the President and he knows about this matter. [...] But the Presidency has never called up the CCC, and the CCC has never had the initiative to say "the CCC has analyzed this matter and it is clearly a fraud." People prefer to not make noise about it. [emphasis added]

Commenting on Mochán's failures to attract an institutional response from the scientific community, Tonini also remarked on the generalized apathy of Mexican scientists to calls for further involvement:

Tonini: Sadly, I am not surprised. It is a symptom of this apathy that the only scientist (or any person with a knowledge of physics) that ever replied to me was someone from Spain. Of all the Mexicans whom I wrote to, or who through common friends I was able to put the data in their hands asking for help to show all the lies behind this pseudoscientific nonsense, nobody ever answered. And there were plenty of them. 
Having had the possibility of being a safeguard or at least a voice against the MD fraud, political interests seem to have set the agenda for these scientific institutions. In preferring "not to make a noise about it," one again sees echoes of non-knowledge and managed-ignorance as an intrinsic part of the Mexican political system, one in which - like for the political actors in Fuentes' novels - silence and behind-the-door dealings are the only recommendable courses of action in the face of infamy and abuses of power.

\section{Conclusions}

The following table summarizes the different institutional dimensions that played a part in the handling of the MD controversy in the US, UK and Mexico:

\begin{tabular}{|c|c|c|c|}
\hline Response & $U S$ & $U K$ & Mexico \\
\hline Media & $\begin{array}{l}\text { Sparse, critical } \\
\text { coverage including } \\
\text { local and scientific } \\
\text { media. }\end{array}$ & $\begin{array}{l}\text { Sparse but very critical. } \\
\text { Investigative journalism } \\
\text { critical in disseminating } \\
\text { MD fraud. }\end{array}$ & $\begin{array}{l}\text { Negligible critical } \\
\text { uptake, even after } \\
\text { fraud uncovered by } \\
\text { isolated investigative } \\
\text { reports. }\end{array}$ \\
\hline $\begin{array}{l}\text { Scientific/academic } \\
\text { institutions }\end{array}$ & $\begin{array}{l}\text { National labs and } \\
\text { scientific government } \\
\text { bodies involved in } \\
\text { early testing of } \\
\text { devices and written } \\
\text { reports. }\end{array}$ & $\begin{array}{l}\text { Academic opinion } \\
\text { decisive in informing } \\
\text { the public of device } \\
\text { frauds through media. }\end{array}$ & $\begin{array}{l}\text { No institutional } \\
\text { responses. Isolated } \\
\text { individual activism. }\end{array}$ \\
\hline $\begin{array}{l}\text { Law enforcement } \\
\text { and military } \\
\text { agencies }\end{array}$ & $\begin{array}{l}\text { Scientific testing of } \\
\text { devices in national } \\
\text { laboratories and } \\
\text { nationwide bans and } \\
\text { alerts. }\end{array}$ & $\begin{array}{l}\text { Immediate bans when } \\
\text { involving UK personnel. } \\
\text { Ambiguous attitude } \\
\text { abroad. }\end{array}$ & $\begin{array}{l}\text { Active opposition to } \\
\text { scientific testing. } \\
\text { Continued to use } \\
\text { MDs despite } \\
\text { evidence against } \\
\text { them. }\end{array}$ \\
\hline $\begin{array}{l}\text { Judicial } \\
\text { institutions }\end{array}$ & $\begin{array}{l}\text { Relatively fast } \\
\text { reaction to scientific } \\
\text { analyses of devices. } \\
\text { Charges raised } \\
\text { against some } \\
\text { manufacturers. }\end{array}$ & $\begin{array}{l}\text { Slow but definitive } \\
\text { action against device } \\
\text { fraud. Heavy fraud } \\
\text { convictions against } \\
\text { manufacturers. Expert } \\
\text { opinion used as trial } \\
\text { evidence in fraud cases. }\end{array}$ & $\begin{array}{l}\text { Individual scrutiny by } \\
\text { a few judges; } \\
\text { inconclusive response } \\
\text { at the highest level. } \\
\text { No legal precedent set } \\
\text { against MDs. }\end{array}$ \\
\hline $\begin{array}{l}\text { Legislative } \\
\text { institutions }\end{array}$ & $\begin{array}{l}\text { Minimal } \\
\text { involvement. }\end{array}$ & $\begin{array}{l}\text { Slow and unconvincing } \\
\text { response to detector use } \\
\text { outside of UK. }\end{array}$ & $\begin{array}{l}\text { Slow and ineffective } \\
\text { reaction. }\end{array}$ \\
\hline
\end{tabular}

The table highlights the significant difference in responses between two GN nations' handling of MDs and the Mexican case - many of the structural characteristics discussed above could clearly be extrapolated to many other GS locations, and certainly across Latin America. While the GN nations could rely on one of many institutional filters to protect from the use of 
(non)technology, for Mexico the lack of visible institutional responses to the MD crisis is critical in understanding the episode. The use of MDs in Mexico has apparently declined and nowadays there are only very sporadic reports by activists of their use. The case seems to have slipped into oblivion and the only other major response was a document by a Lower Chamber representative to begin an inquiry into the GT200 case in 2014, causing no further action. ${ }^{41}$ It seems then that the Mexican Government's generalized tactic of letting a grave issue "die in silence" - along with the press, the UNAM authorities, the Supreme Court, the CCC and the British Governmentwas successful in avoiding public embarrassment for many. Also avoided were public scrutiny, a deep understanding of the issues at stake and the fortification of a democratic approach to demarcating technology from (non)technology. Critically, still missing is a comprehensive detailing and full revision of all on-going judicial cases where MDs were used to detain persons, and thus of righting what could be thousands of unwarranted and illegal detentions.

In terms of its relevance to recent calls for more "situated" and "engaged" STS scholarship, the case has involved actors that do not fit comfortably inside the traditional STS policymaking frameworks and therefore destabilizes focus on the direct translation of expert vs. layperson discussions as understood in the dominant STS models. The figures of scientist-asactivist, scientist-as-citizen, the underpowered-scientist and the uninterested-public display the vast differences between North and South circumstances, and thus underscore the need to create models of scientific and technological policymaking that from the start reflect these dissimilarities in their approach to policymaking and science-politics relations. The MD case also shows the power that a nuanced constructivist account can have, in highlighting the different outcomes that come from holding different positions on both the discursive and the realized impact of science on societies, and on social and political justice in different settings. In this sense, it is not enough to simply analyze the MD episode and provide an analytical, "symmetrical" account of (non)technology construction, without, as Winner (1993) remarked, taking full consideration of the impact that these (non)technologies have in the societies that enable them, and on the role that carrying out these tasks can have in promoting different social relations between sciences and societies.

Secondly, the MD case brings attention to the critically important role that scientific institutions have in national contexts that are unprepared for the introduction of "globalized" destabilizing science, technology and (non)technology due to their "peripheral" positions (Batteau 2009, Hwang 2007). It also highlights the unethical nature of a GN nation that allows the proliferation of homemade (non)technology due to its economic self-interests; it simultaneously also shows that a corresponding lack of appropriation of science by a GS nation almost ensures its vulnerability to these unethical practices. The case finally illustrates the consequences against open democratic deliberation on technological issues implied by the lack of strong, autonomous and socially engaged scientific institutions. In this sense, the analysis of (non)technology diffusion presented here coincides with Rodríguez Medina's $(2014,237)$ view that "Analysing dependence is not... an attempt to move the burden of responsibility to the centres of production" but rather that, "the mechanisms developed in the periphery contribute to the asymmetry between local and foreign knowledge."

\section{Bibliography}

W Anderson (2009). From subjugated knowledge to conjugated subjects: science and globalisation, or postcolonial studies of science? Postcolonial Studies, 12(4): 389-400. 
M Ashmore (1993). The theatre of the blind: Starring a promethean prankster, a phoney phenomenon, a prism, a pocket, and a piece of wood. Social Studies of Science, 23(1): 67-106.

AW Batteau (2009). Technological peripheralization. Science, Technology \& Human Values, 35(4): 554-574.

E Beatty (2015). Technology and the Search for Progress in Modern Mexico. Oakland, CA: University of California Press.

C Bonneuil, J Foyer and B Wynne (2014). Genetic fallout in bio-cultural landscapes: Molecular imperialism and the cultural politics of (not) seeing transgenes in Mexico. Social Studies of Science, 44(6): 901-929.

R Booth (2014). UK Government promoted fake bomb detectors. The Guardian Online, 20 August 2013. Accessed 25 July 2016.

M Brandt (2014). Zapatista corn: A case study in biocultural innovation. Social Studies of Science, 44(6): 874-900.

ND Campbell (2005). Suspect technologies: scrutinizing the intersection of science, technology, and policy. Science, Technology \& Human Values, 30(3): 374-402.

H Campbell (2014). Narco-Propaganda in the Mexican "Drug War": An Anthropological Perspective. Latin American Perspectives, 41(2): 60-77.

WB Carpenter (1852). On the influence of suggestion in modifying and directing muscular movement, independently of volition. Proceedings of the Royal Institution: 147-1540.

HM Collins and R Evans (2002). The Third Wave of Science Studies: Studies of Expertise and Experience. Social Studies of Science, 32(2): 235-296.

HM Collins and TJ Pinch (1982). Frames of meaning: The social construction of extraordinary science. London: Routledge \& Kegan Paul.

P Dávila (2102). Los detectores y la 'ingenuidad' mexicana. Proceso. 1838. 22 January, 2012.

JA De la Peńa. (2005). La percepción pública de la ciencia en México. Revista Ciencias 78: 3036.

R Ennals (2014). Responsible Management in Governmen, in R Ennals (editor), Responsible Management: Corporate Responsibility and Working Life. CSR, Sustainability, Ethics and Governance. Springer Berlin Heidelberg: 131-140.

A Hernández (2010). Los señores del narco. Mexico City: Grijalbo.

V García-Deister and C López-Beltrán (2015). País de gordos/país de muertos: Obesity, death and nation in biomedical and forensic genetics in Mexico. Social Studies of Science, 45(6): $797-$ 815. 
C Galindo (2013). La ouija del diablo. Mexico: Ediciones B.

D Graeber (2006). Beyond Power/Knowledge an exploration of the relation of power, ignorance and stupidity. Malinowski Memorial Lecture, London School of Economis, 25 May.

K Hwang (2007). International collaboration in multilayered center-periphery in the globalization of science and technology. Science, Technology \& Human Values, 33(1): 101-133.

S Jasanoff (1990). The Fifth Branch: Science advisers as policymakers. Cambridge, MA: Harvard University Press.

S Jasanoff (editor) (2004). States of knowledge: the co-production of science and the social order. London: Routledge.

S Jasanoff (2005). Designs on nature: Science and democracy in Europe and the United States. Princeton, NJ: Princeton University Press.

T Kellner and F Pipitone (2010). Inside México's drug war. World Policy Journal, 27(1): 29-37.

P Kreimer (2006). ¿Dependientes o integrados? La ciencia latinoamericana y la división internacional del trabajo, Revista Nómadas: 24.

AG López-Montiel (2000). The military, political power, and police relations in Mexico City. Latin American Perspectives, 72(2): 79-94.

M Levi (2008). Organized fraud and organizing frauds: Unpacking research on networks and organization. Criminology and Criminal Justice, 8(4), 389-419.

H Lutz (1996). Human rights in Mexico: A policy of impunity. New York; Human Rights Watch.

N Maldonado-Torres (2012). "Epistemology, Ethics, and the Time/Space of Decolonization: Perspectives from the Caribbean and the Latina/o Americas", Decolonizing Epistemologies, ed. Ada Maria Isasi-Diaz and Eduardo Mendieta. New York: Fordham University Press.

AS Mathews (2008). State making, knowledge, and ignorance: Translation and concealment in Mexican forestry institutions. American Anthropologist, 110(4): 484-494.

AS Mathews (2014). Scandals, audits, and fictions: Linking climate change to Mexican forests. Social Studies of Science, 44(1): 82-108.

E Medina, I da Costa Marques and C Holmes (2014). Introduction: Beyond imported magic. In Beyond imported magic: Essays on science, technology, and society in Latin America, Cambridge, MA: The MIT Press: 4-8.

Mitofsky (2014). Décima tercera encuesta nacional sobre percepción de inseguridad ciudadana en México. Consulta Mitofsky. March, 2014. Retrieved July, 2014. 
http://mucd.org.mx/recursos/Contenidos/EncuestaMitofskydePercepcinCiudadanasobrela/docu mentos2/NAMUCD2014mzoRoy.pdf

DW Murray, FW Spencer and DD Spencer (1998). Double-blind evaluation of the DKL LifeGuard Model 2. Sandia Report SAND98-0977/UC-600, Albuquerque: Sandia National Laboratories.

WL Mochán (2011). Análisis de la ficha documental de operación del GT-200. Published online: http://em.fis.unam.mx/public/mochan/blog/20110620gt200.pdf

WL Mochán and A Ramírez-Solís (2013). Efectiveness of the GT200 Molecular Detector: A Double-Blind Test. arXiv:1301.3971 [physics.soc-ph]. Retrieved: 21 July, 2014.

DW Murray (2002). Double-blind field evaluation of the MOLE programmable detection system. Albuquerque: Sandia National Laboratories.

TJ Pinch (1979). Normal explanations of the paranormal: The demarcation problem in fraud and parapsychology. Social Studies of Science 9: 329-48.

TJ Pinch and HM Collins (1984). Private science and public knowledge: The Committee for the Scientific Investigation of the claims of the Paranormal and its use of the literature. Social Studies of Science, 14(4): 521-546.

A Quijano (2007). Coloniality and modernity/rationality. Cultural Studies, 21(2-3): 168-178

B Rappert and B Balmer (2015). Ignorance is strength? in M Gross, M and L McGoey (editors). Routledge International handbook of ignorance studies. London: Routledge: 328-337.

L Rodríguez Medina (2014). Centers and Peripheries in Knowledge Production. New York: Routledge.

LI Reyes-Galindo (2012). Expertise side-lined: Science, fraud and bogus molecular detectors in the Mexican 'War on Drugs', presented at SEESHOP6 Workshop, June 8, 2012. URL: http://ssrn.com/abstract=2174437

FR Sagasti (1973). Underdevelopment, science and technology: the point of view of the underdeveloped countries. Social Studies of Science, 3(1), 47-59.

YK Shin, RW Proctor and JE Capaldi, (2010). A review of contemporary ideomotor theory. Psychological Bulletin, 136(6): 943-974.

J Schnabel (1994). Puck in the laboratory: The construction and deconstruction of hoaxlike deception in science. Science, Technology \& Human Values, 19(4): 459-492.

M Schoijet and R Worthington (1993). Globalization of science and repression of scientists in Mexico. Science, Technology \& Human Values: 18(2), 209-230. 
W Shrum (2005). Reagency of the internet, or, how I became a guest for science. Social Studies of Science, 35(5): 723-754.

and W Shrum and Y Shenhav (1995) Science Technology in Less Developed Countries, in $S$ Jasanoff et al (eds), Handbook of Science, Technology and Society Studies, Newbury Park, CA: SAGE Publications: 627-51.

EM Schur (1957). Sociological analysis of confidence swindling. The Journal of Criminal Law, Criminology, and Police Science, 48(3), 296-304.

B Sovacool (2008). Exploring scientific misconduct: Isolated individuals, impure institutions, or an inevitable idiom of modern science? Journal of Bioethical Inquiry, 5: 271-282.

L Stephen (1999). The construction of indigenous suspects: militarization and the gendered and ethnic dynamics of human rights abuses in Southern Mexico. American Ethnologist, 26(4): 822842.

A Tonini (2010). El Neo-Zahorismo tecnológico. El Escéptico, 31/32: 77-87.

US Navy (2008). Test report: The detection capability of the Sniffex handheld explosives detector. Indian Head, MD: Naval Explosives Ordnance Disposal Technology Division. Retrieved from http://s3.amazonaws.com/propublica/assets/docs/NavyReport.pdf

E Vulliamy (2010). Amexica: war along the borderline. London: Random House.

L Winner (1993). Upon opening the black box and finding it empty: Social constructivism and the philosophy of technology. Science, Technology, and Human Values: 362-378.

B Wynne (1992). Misunderstood misunderstandings: Social identities and public uptake of science. Public understanding of science, 1(3): 281-304.

\footnotetext{
${ }^{1}$ For an extended history of MDs in Mexico, see Reyes-Galindo (2012) and Galindo (2013).

${ }^{2}$ R. Booth. "Fraudster paid government to help promote fake bomb detectors". The Guardian online, 26 January, 2014. Accessed 4 August, 2015. http://www.theguardian.com/politics/2014/jan/26/fraudster-paid-governmentpromote-fake-bomb-detectors

${ }^{3}$ Discussions of fraud in the STS literature can be widely grouped into three types: the first encompasses analyses of scientific "fraud" as cases of deception and intentional rule-breaking carried out by scientists for personal gain (Sovacool 2008); the second looks at fraud in the form of "hoaxes", understood as deceptions that have a "milder, more playful nature" compared to personal-gain scientific fraud (Ashmore 1993, Schnabel 1994); last is a series of studies that destabilize mainstream scientific discourse on "fringe" fields as intrinsically fraudulent or deceptive practices, particularly in regards to so-called "skeptic" accounts (Collins and Pinch 1982; Pinch 1979; Pinch and Collins 1984).

${ }^{4}$ R. Booth. "Kent businessman jailed for seven years over fake bomb detectors". The Guardian online, 20 August, 2013. Accessed 4 August, 2015. http://www.theguardian.com/uk-news/2013/aug/20/gary-bolton-jailed-seven-yearsfake-bomb-detectors

${ }^{5}$ J. J. Lemus, "La Ouija del diablo”. Reporte Índigo, 28 July 2015. Accessed 3 August 2015.

http://www.reporteindigo.com/reporte/mexico/la-ouija-del-diablo
} 
6 "Más de 121 mil muertos, el saldo de la narcoguerra de Calderón: INEGI". Proceso (Online versión), 3 July 2013. Retrieved 14 January, 2016. URL: http://www.proceso.com.mx/?p=348816.

${ }^{7}$ A. Becerril, "Nueva arma de Sedena pone a temblar al narco", 1 October, 2010. Originally published in Excélsior newspaper, republished in Vanguardia, retrieved: 28 July, 2014, but no longer available online.

${ }^{8}$ Id.

9 Reuters. "Iraq: Official Arrested in Connection With Bogus British Bomb Detectors".

The New York Times online. Published: February 17, 2011 checked 12 October, 2012.

http://www.nytimes.com/2011/02/18/world/middleeast/18briefs-Iraq.html

${ }^{10} \mathrm{http}: / /$ lonjho.blogspot.com.br/2011/03/los-distribuidores-del-gt200-y-otros.html

${ }^{11} \mathrm{http}: / /$ www.segtec.com.mx/segtec/quienes-somos

${ }^{12}$ C. Hawley, Newsnight, Friday, 22 January 2010.

${ }^{13}$ C. Hawley, M. Jones. "Export ban for useless 'bomb detector". BBC Newsnight. 22 January 2010. Retrieved: 28

May, 2014. http://news.bbc.co.uk/1/hi/programmes/newsnight/8471187.stm

${ }^{14} \mathrm{~L}$. Benedictus, "Why are countries still using the fake bomb detectors sold by a convicted British conman?". The Guardian Online, Monday 9 June 2014. Retrieved: 22 July, 2016.

${ }^{15}$ The full text of the letter is available at: http://explosivedetectorfrauds.blogspot/2009/10/global-technical-morelies.html

${ }^{16}$ http://explosivedetectorfrauds.blogspot.mx/2010/02/secret-royal-engineer-test-reporton.html

${ }^{17}$ http://lonjho.blogspot.co.uk/

${ }^{18} \mathrm{~A}$. Tonini, personal communication with the author.

${ }^{19}$ Interview, 2012.

${ }^{20}$ L. Mochán, "Magia Ciencia Salud y Seguridad Nacional", La Unión de Morelos, 6 September, 2010.

${ }^{21}$ The full recording of the Senate meeting. Retrieved: 28 July, 2014.

https://www.youtube.com/watch?v=baWlA4K5GWw

22 "Dictamen de la proposición con punto de acuerdo...". Primera Comisión, Gobernación, Puntos

Constitucionales y Justicia, Poder Legislativo Federal, Comisión Permanente. 5 June, 2012. Retrieved: 28 July,

2014. http://www.senado.gob.mx/sgsp/gaceta/61/3/2012-06-06-1/assets/documentos/1ra_Com_detector_GT200.pdf

${ }^{23}$ B. Jiménez, R. Herrera. "Compra Sedena equipo 'milagro'”. Reforma, National News section. 26 March 2011.

${ }^{24}$ Interview with the author.

${ }^{25}$ Id.

${ }^{26}$ All of Mexico's indigenous communities are an extremely vulnerable population and the target of discrimination by the wider society and human rights abuses by authorities. See Stephen (1999). Campbell (2004) has illustrated how contentious technologies are particularly prone to affect minorities.

${ }^{27}$ http://em.fis.unam.mx/blog/mochan/varios/20130501gt200.html

28 "Recomendación General No. 19: Sobre la práctica de cateos ilegales". Comisión Nacional de Derechos

Humanos, Diario Oficial de la Federación. 12 August, 2011. Retrieved: 28 July, 2014.

http://www.dof.gob.mx/nota_detalle.php? codigo $=5204643 \&$ fecha $=12 / 08 / 2011$

29 "Solicitud de ejercicio de la facultad de atracción 2/12". First Chamber of the National Supreme Court, Mexico City. 29 August, 2012. Retrieved: 28 July, 2014.

http://www2.scjn.gob.mx/juridica/engroses/cerrados/Publico/12003420.024-1302.doc

${ }^{30}$ https://www.scjn.gob.mx/libreria/Decima2012Docs/OCT_2012.pdf

${ }^{31}$ http://www.technologyreview.com/view/510156/physicists-prove-dowsing-bomb-detectors-useless-in-double-

blind-trial/

${ }^{32} \mathrm{http://www.bbc.co.uk/news/uk-england-beds-bucks-herts-28602876}$

${ }^{33}$ https://www.youtube.com/watch?v=t4BgzTwaqZw

${ }^{34}$ Skeptics and activists often mention the "ideomotor effect" as the cause of MD proliferation, a term coined by Carpenter (1852) to causally relate actors' beliefs to their actions during occult and psychic demonstrations (Tonini 2010). Ideomotor theory proposes that "internal images of actions and the actions themselves are tightly linked or that perceptual events tend to generate actions for which the feedback is similar" (Shin et al 2010, pg. 934).

35"Encuesta Nacional sobre la Percepción Pública de la Ciencia y la Tecnología 2011 (ENPECYT)", Instituto

Nacional de Ciencia y Geografia, INEGI. Retrieved: 28 July, 2014.

http://www.inegi.org.mx/est/contenidos/proyectos/encuestas/hogares/especiales/enpecyt/2011/default.aspx

${ }^{36} \mathrm{http} / / /$ contralinea.info/archivo-revista/index.php/2014/07/13/corrupcion-suicido-en-la-defensa/ 
${ }^{37}$ Bolton nevertheless has consistently claimed that" Royal Engineer Export Support personnel [...] regularly issued copies of the report to visiting foreign government representatives to assist in the promotion of the device" (Booth 2014).

38 "UKTI dealings with fraudster Gary Bolton - full documents". The Guardian online, 26 January 2014. Accessed 4 Augusta 2015. http://www.theguardian.com/uk-news/interactive/2014/jan/26/ukti-gary-bolton-documents 39 "Embajada británica promovió la 'ouija del diablo' en México: Luis Mochán". Aristegui Noticias. URL: https://www.youtube.com/watch?v=0P-takKPX2Y

${ }^{40}$ Not surprisingly, Mexico has a track record of passively silencing academic voices that are seen as dissenting from government policy by using institutional structures (Schoijet and Worthington 1993).

${ }^{41}$ http://sil.gobernacion.gob.mx/Archivos/Documentos/2014/03/asun_3082901_20140318_1395250974.pdf 